\title{
LIBRARY STATISTICS DATABASE OF THE NATIONAL UNIVERSITY OF LA PLATA (ARGENTINA): A COOPERATIVE EXPERIENCE
}

\author{
Marcela Fushimi, Director of the Faculty of Humanities Library \\ Norma Mangiaterra, ROBLE UNLP Library Network Coordinator \\ Mariana Pichinini, Technical Services, Faculty of Humanities Library \\ A.S. Gustavo Archuby, Director of Computer Systems Area, Faculty of \\ Humanities (National University of La Plata Argentine)
}

\section{THE NATIONAL UNIVERSITY OF LA PLATA}

The history of the National University of La Plata (UNLP) begins in the late $19^{\text {th }}$ century, when the National Congress proposed the establishment of a university in the recently founded city of La Plata, the new capital of the province of Buenos Aires. The proposal came as an answer to the new training needs for the younger generation in scientific, technical and cultural field areas.

Founded in August 1905 by Dr. Víctor Joaquín González, UNLP emerged as a modern university, far from the strictly 'academic profile' of these educational institutions. More than a century old, it remains a pioneer in cultural, artistic and scientific research and development. This has given the prestige that sets it among the main universities in the country, the American continent and the world. Teaching, research and extension programmes stand as the pillars of our university, and as all public universities in Argentina, access is free for everybody who wishes to study in there.

It currently has 17 faculties that cover all areas of knowledge: Astronomy and Geophysics, Earth Sciences, all kinds of Engeneering, Maths, Physics and Chemical Sciences, Natural Sciences, Medicine and Dental, Veterinary, Architecture, Computer Sciences, Journalism and Communication Studies, Psychology, Arts, Humanities, Education, Sociology and Social Sciences with about 90,000 students. In recent years it has registered an average enrolment of over 20 thousand candidates per year. Anually over 5,000 new professionals graduate and leave their classrooms.

The academic offer includes 116 grades, 153 titles and 150 postgraduate courses, 33 doctorates, $60 \mathrm{MA}$ courses and 57 specializations. About $60 \%$ of them have been accredited by the National Commission for University Evaluation and Accreditation, CONEAU.

It also has five Secondary and Primary Schools with an enrollment of approximately 4,800 students. The total community is made up of more than 10,000 professors and 2,500 professionals, administrative and service staff. 
The University also has over $130 \mathrm{R} \& \mathrm{D}$ Institutes, Centers, Labs and Units (16 shared with CONICET ${ }^{1}$ ) where some 3,000 researchers and 400 fellows develop their activities in over $600 \mathrm{R} \& \mathrm{D}$ projects.

There is also a Museum of Natural Science (and a network of 12 thematic museums), an Astronomical Observatory, a Center for Genome Studies, a Public Library (and a network of 22 libraries), an Editorial house, an AM-FM Radio, an Institute of Physical Education with an Open Sports Center, a Leisure House called Samay Huasi in Chilecito, La Rioja, and astronomical stations, geomagnetic fields and experimental plots in various provinces.

By the end of 2004, a long awaited dream came true: UNLP reopened the University Dining Room, which was closed in the mid 70's. Today more than 5,000 students eat there.

The total area covered by its facilities exceeds $280,000 \mathrm{~m}^{2}$. Because of its history, it is the third university in the country (after the University of Buenos Aires UBA - and the very close National University of Cordoba (UNC)) and the largest in the province of Buenos Aires. In fact, $90 \%$ of its enrolment are students from different towns of the province. UNLP holds one of the most complex academic tapestries in Latin America, given its wide offer of courses, research areas, exchange and extension programmes, and social integration.

\section{ROBLE $^{2}$, THE UNLP LIBRARY NETWORK}

On January 18, 1887, the Executive Branch of the newly born Buenos Aires province created the Provincial Public Library to initiate a bibliographic collection that was meant to constitute the basis for future research in different areas of knowledge. In 1905 when UNLP was created, this library was transfered to its premises. Since then, it has held more than 41,000 bibliographic volumes, including the 'Cervantina', a collection of outstanding significance ${ }^{3}$.

Parallel to the creation of individual faculties and academic units comprising UNLP, libraries for UNLP schools were created as well. In 1967 Roberto Couture de Troismonts ${ }^{4}$ managed and ran the Public Library, and proposed the develop-

National Council of Scientific Research = Consejo Nacional de Investigaciones Científico-Tecnológicas [on line] www.conicet.gov.ar

2 Two green leaves of oak is one of the symbols that identifies the UNLP. That's why the Library Network choose this name (ROBLE) and image. More information about this is available at: http:// www.biblio.unlp.edu.ar/new/simbolos.html [last accessed 14-7-2008]

3654 treasure volumes with editions of great bibliophile and literary value of the works of Miguel de Cervantes Saavedra of the sventeenth and eighteenth centuries in a variety of languages and translations. More information about this is available at: http://www.biblio.unlp.edu.ar/new/col_esp.html [last accessed 14-7-2008]

4 Couture de Troismonts (1918-2001), descendant of French emigrant parents, born in Buenos Aires and in 1936, when completed his studies, he began working on the Central Bank of Argentina (BCRA). In 1945 he began to work at the BCRA Library and from there comes his first contact with the library. Self-taught in its infancy, avid reader of specialized texts of the discipline, began work in 
ment of the Library System of the National University of La Plata (Res. 859), as part of a rationalisation plan by which the 'Advisory Commission of the Library' was created. This Comission was made up of representatives of all faculties and colleges, and its purpose was to establish a joint procurement policy for bibliographic materials. The 'Librarians' Technical Committee', made up of directors of the libraries of Faculties and Institutes of the University, took an active role in all aspects regarding to librarianship and the coordination of the Library System.

Couture's management (1967-1973) was advanced for that time in our country: the Public Library became the head of the UNLP Library System. He got a new budget for the purchase of scientific literature, which allowed at that time to buy the entire academic production of Argentina. He worked in coordination with the different Faculty Libraries, and created the first Scientific Documentation Centre in response to the information load and the need for specialized services for science and scientific research. Moreover, he began publishing a monthly news bulletin called Reports of the Library, published and distributed the Argentinian University Bibliography on cards, launched a programme of microfilm for newspapers and organised numerous cultural activities (exhibitions, workshops, conferences).

After Couture's resignation, and as a result of the profound political and institutional crisis that led to the military dictatorship, the Public Library lost its leadership and the Library System ceased to function as such. From that date onwards, the position of Director of the Public Library was occupied by successive political leaders who gave no continuity to the original project. And although the situation began to improve with the advent of democracy in 1983, it was not until the end of the 90s that libraries in the UNLP started to organize themselves to work in coordination.

But at this time the need for coordination came from the libraries of Colleges and Faculties themselves, which together with the Public Library were the ones that proposed a structure of cooperative work, based on the formation of Interlibraries Task Forces (ITFs) devoted to the study and development of specific projects, with the ultimate aim of forming the UNLP Library Network.

This has been the beginning of ROBLE, initially as a Web Portal that would be the specific location where the Libraries may be displayed at once, and then as an area of cooperative work. The people committed to the project have been working on various libraries of the UNLP, and were interested in this project. The initial ITFs teams have been working on:

organizing numerous libraries. In 1950 obtained a grant from the French government to refine their studies in Europe, travel would be crucial to its formation, and that would result, upon his return, the introduction of a new orientation in the discipline in Argentina: the 'documentation'. This is clearly reflected in this stage of the career created librarianship in La Plata, and in his actions as head of the UNLP Public Library, in particular the creation of the Documentation Centre, unique and novel to date by its modern conception. (Parada, 2003) 
- ITF Portal, with a team dedicated to the creation of ROBLE Web Portal

- ITF Evaluation of Information Units, with a team dedicated to develop indicators of library management

- ITF Formats / Software, with a team dedicated to studying software formats in use in various libraries for the integration of a collective catalog

Today, the UNLP Library Network consists of 22 libraries of various kinds: one public and central library, sixteen specialized faculty libraries, and five school libraries (primary and secondary education). Although they still do not formally integrate the network, libraries from centers, laboratories and specialized research institutes dependant on UNLP are being gradually incorporated to the net.

According to the latest survey conducted in 2007, in 18 of these 22 net-libraries there are collections exceeding one million monographic volumes and about 19.000 titles of serials (of which about 2.000 collections are current serials). Only $60 \%$ of the total collection is computerized, while $40 \%$ of Libraries have implemented a system of automated loan management. Libraries occupy about $14.000 \mathrm{~m}^{2}$, and nearly 250 persons work there, around $40 \%$ of whom are professional librarians.

\section{BACKGROUND OF THE ITF EVALUATION OF INFORMATION UNITS}

The first statistical survey conducted by UNLP Libraries dates from 1997 and its completion was linked to the need to know the progress of computerization, of both books and serials, with the intention of shaping an automated collective catalog accessible via the Internet, since the UNLP had become part of the ISTEC ${ }^{5}$ consortium.

In the same year, the SIU Libraries module ${ }^{6}$ conducted a national survey to collect basic facts about national university libraries, in parallel with the gradual implementation of many $\mathrm{FOMEC}^{7}$ projects in the country, that were oriented to improve the infrastructure and collections of libraries and staff training.

In 1999 the UNLP Libraries coordinated in conjunction with the Science and Technology Secretariat of the UNLP, organized the 'Primera Jornada de Intercambio de experiencias de las Bibliotecas', ${ }^{8}$ which took place in December, where each library had the chance to express and share its projects and experiences with

\footnotetext{
Ibero-American Science \& Technology Educational Consortium www.istec.org

6 SIU = Sistema de Información Universitaria (University Information System) del Ministerio de Educación de la Nación www.siu.edu.ar

7 Fund for the improvement of educational quality. Program of allocation of resources for development and financing of projects dedicated to improve higher education in national universities implemented by the University Policy Secretariat of the Ministry of Education of the Nation since 1995

8 Workshop on Experience Exchange of UNLP Libraries
} 
others. On that occasion it was re-distributed a survey to reveal library statistics. This survey was more comprehensive in content than the previous one, and was taken from the Spanish statistical model used by REBIUN ${ }^{9}$.

Even though a report ${ }^{10}$ was produced with the data collected, little could be done to continue with a concrete plan of action since our efforts were not supported by our authorities.

In October 2001 ROBLE was created as the UNLP Library Network. The Public Library restored its historic role as a central coordinator node, and the Interlibraries Task Forces mentioned before were formed. The effect was immediate: joint projects that were delayed by lack of budget and motivation were quickly put into practice.

In addition, the ITF Evaluation of Information Units, was established with the aim of developing 'management indicators applicable to all libraries of the UNLP in order to measure and diagnose them. In this way, the ITF team facilitated and improved decision making processes. ${ }^{11}$

The ITF slightly updated the statistical form used earlier, which was distributed in digital format (spreadsheet). This includes automatic calculation of total, subtotals and a group of specially selected indicators to get a picture of the status of libraries at that time. The procedures of this survey were published in 2003 in the First Statistical Yearbook of the UNLP Libraries that yielded an diagnostic overview of libraries in 2001. Incidentally, at the same time, the University launched a long term process of self-assessment in all its areas, for the development of an strategic plan for 2004-2007.

Meanwhile, the ITF continued working in the statistical survey. Similar experiences in other countries were compiled and contrasted to the information in our survey, such as:

- REBIUN Red de Bibliotecas Universitarias y Científicas (España)

- CABID Comisión Asesora de Bibliotecas y Documentación del Consejo de Rectores de las Universidades Chilenas (Chile)

- CAUL Council of Australian University Librarians (Australia)

- ARL Association of Reseach Libraries (Norte América)

- SCONUL Society of College, National \& University Libraries (Reino Unido)

- CARL Canadian Associaton of Reseach Libraries (Canadá)

- NISO National Information Standards Organization (USA)

Based on the information gathered, the survey form was modified and updated to carry out a new statistical survey in all libraries. The major changes made in the 2002 version of Statistic Form were:

9 REBIUN = Red de Bibliotecas Universitarias y Científicas Españolas (Spanish Academic and Scientific Library Network) www.rebiun.org

10 That report is available at the WEB of ROBLE > Statistics > Report 1999

11 Cooperative Work Plan 2003-2004. ETI / Evaluación de UI. Available at: http://www.roble.unlp. edu.ar/menu1_1.htm\# 
- We made a distinction between mandatory and optional fields, so as to ensure that all libraries at least completed the compulsory ones

- Data added: number of certificates, degrees, postgraduates and disciplines in which each Faculty or School was specialized

- Some fields were simplified (details of equipment available, staff activity, technical processes and computerization, etc.)

- We added to points 7 (collections), 8 (use of services) and 10 (budget) a special section to collect data about the existence, use and cost of electronic resources

- We added the point Discard, to assess this aspect of collection development

- The use of different services were unified in section 8. In addition to the use of electronic resources. measuring of reference transactions and users training activities were added

- We wrote an instructive manual with detailed definitions, examples and suggestions for the proper filling of the form, based on standard Z39.7

This new form was implemented in 2005 and the second Statistical Yearbook of the UNLP Libraries was prepared. The survey data was conducted in the form of a spreadsheet that libraries completed and sent to the ITF for centralized processing and analysis. Methodologically operating, the survey showed the expected results, but the following problems were faced:

- manual processing of the data was extremely cumbersome and prone to human errors in typing,

- tailoring and subsequent publication of the Statistical Yearbooks was delayed by two years, since there was no staff dedicated exclusively to this task,

- processed data was not registered in a public place or was easily accessible, so any subsequent study was difficult to implement, and,

- because of the excesive delay in processing, there was no time to move on comparative or more developed studies within libraries (benchmarking, second-level indicators, impact indicators, etc.).

For these reasons, during 2007 funds were managed to develop a Web application that would allow us to automate the statistical survey and generate a data base with all the data of the UNLP libraries collected since 2001.

\section{DEVELOPMENT OF THE WEB APPLICATION}

The concrete example that was consulted as a model for the development of this application was the SCONUL statistical form, which could be accessed via the Internet in test mode. We also checked other similar developments ASIBU $^{12}$ and

12 ASIBU Annarie statistique interactive des bibliotheques universitaires [on line]. - http://www.sup. adc.education.fr/asibu/ [consulted 12-7-2008] 
REBIUN). It was not possible to have access to the data loading screens of these last two models but we were able to access to the search interface and visualization. The goals set were:

- To allow access to the data entry of statistics from each of the libraries of the network through a web form

- To generate a database containing statistical information provided by each library

- To automate data processing, including the calculation of indicators and the generation of reports and graphs

- To allow the distribution and exchange with other libraries interested in this evaluation methodology

- Figure 1 shows the structure of the application

The first level is the institution level, which can be a University, a Faculty, School, Department, Institute, College, etc. This was made like this because of the complex tapestry of the UNLP as was explained before, and to allow the use of the application by others universities.

Inside the Institutions, we create the libraries, and inside the libraries we create the statistical forms. Each library can create one or more statistical forms according to their available data, one for each complete academic year.

The statistical form is divided into ten subforms that comprises the defined categories: Opening (apertura), Infraestructure (locales), Equipment (equipamiento), Users and population (usuarios y población), Disciplines and Grades (carreras y disciplinas), Collection (colecciones), Services (servicios), Computarisation (informatización), Staff (personal) and Budget (presupuesto).

Each subform contains the data fields. For example, Infrastructure contains: total surface of the library, total surface of the parent institution, number of seats, total meters of open stacks, total meters of closed deposits, percentage of the surface dedicated to users, to staff and to collections and access to the internet $(\mathrm{y} / \mathrm{n})$.

From these nine fields, only three are mandatory (total surface of the library, number of seats and access to the internet) because they are needed to calculate the basic indicators. When a library creates a statistical form (for example, the 2007), it should complete at least all the mandatory data in all the subforms.

If the library completes all the fields (mandatory and optional), the application will show the complete list of indicators, ${ }^{13}$ which are the following:

- Percentage of penetration of the library services in the population served

- Opening hours

- Available surface per user

- Space distribution (users, collections, staff)

- Proportion library surface / parent institution surface

${ }^{13}$ For a complete description of the criteria used for data fields and indicators, see the Instruction manual in the application at www.roble.unlp.edu.ar 


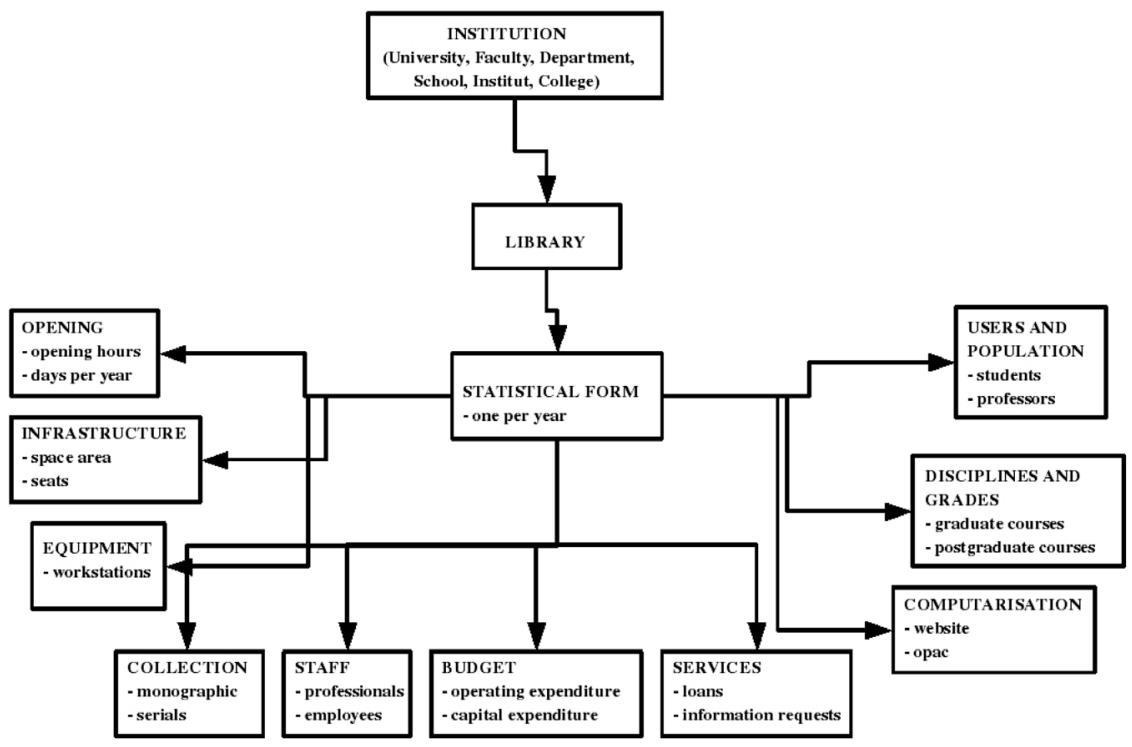

Figure 1: Web application structure

- Users per seats - Students per seats

- Proportion of collection located in open stacks / closed deposits

- Computers per librarian and Internet computers per users

- Monographic volumes per field, grade, and user

- Current serials per professor

- Special materials per user

- Electronic resources per user

- Monographic volumes added per user

- Percentage of computarisation advance

- Electronic information (website, opac, loan management system)

- Total services use registered by day, hour and user (in house use + loans + information requests + interlibrary lending + user training)

- Loans and in house use by day

- Loans and in house use per user

- Percentage of the total populations reached by user training activities

- Other services indicators

- Percentage of librarians from total staff

- Users by staff

- Capital expenditure used to the acquisition of bibliography, per user

- Total capital expenditure available per user

- Operating expenditure per opening day and hour

- Operating expenditure per user 
- Operating expenditure per loan

- Total budget available per user

- Budget distribution (collection development, equipment, salaries and ordinary expenses)

- Budget origin (parent institution, external funds)

- Proportion library budget / parent institution budget

The selected indicators and data fields included in the application were the most common and usually mentioned in the library standards and statistical yearbooks consulted. We gave special emphasis to some aspects in which the UNLP libraries are weak (for example, infraestructure, buildings, budget), just because we wanted to highlight these problems to alert our authorities.

Among the minimum features the application meets, we can state the following:

- it provides control access and management of different levels of users and permissions (administration and data entry), so that each library could edit their own data through the Web

- Version 2004 of the statistical form was taken as the basis for its design and content

- it includes instructions and on-line help, general and contextual links to the loading screens, based on the last version 2004

- it allows validation of fields and areas, showing warnings and messages about errors or inconsistency in the data loading

- it allows the generation of reports, graphs and tables similar to those made in previous Yearbooks

- it allows data store from all libraries and previous statistical series (2001 and 2004), with the idea of implementing an interface for future consultation of the data

Among the technical requirements, we mentioned the possibility that the system should be scalable, distributable and configurable to different needs considering its possible application in other institutions. Moreover, special emphasis was given to the following aspects of the application: to respect the aesthetic criteria of preexisting ROBLE Portal (look and feel) as well as the accessibility standards and regulations of the W3C, use of trademarks, XHTML and CSS.

Finally, the application was run by a Linux-based platform Python + Zope + Plone software, because among the members of the ITF where developers, programmers, designers and librarians with expertise in the subject, both from the point of view of programming as from the use and operation of the system ${ }^{14}$. Moreover, the idea of using a content management system for WEB (CMS) was functional to another longer-term objective, which is to enable a virtual workspace for the library network, to form an intranet.

${ }^{14}$ The software used for this development is the same that has been put into operation one year earlier for the development of the Faculty of Humanities and Educational Sciences WEB Portal 
The team that developed this application was: interdisciplinary: librarians specified the initial technical specifications, developers designed and programmed the software application, then librarians tested again the application and loaded the inicial data, corrections were made and finally the system was put into operation in mid-2007.

After a brief workshop in which we taught the application to librarians of the net, each library recorded their statistical data for 2006 in the WEB form. The team reviewed the loaded data and made the necessary corrections on each form. We also inserted data from previous surveys to check the consistency of the application. This allowed us to get the specific product that is available today online: the statistical database of UNLP libraries (2001, 2004 and 2006), which can be seen at the ROBLE Portal in www.roble.unlp.edu.ar.

Once this first stage was over, programming continued to allow the generation of summaries of data and displayed automatic calculated tables that resulted from the selection of specific indicators, e.g. each library in a given year, each library over time, and all libraries with one another.

Some of this work and its progress was introduced in the Workshop of Library Evaluation Indicators (http://tieb.fahce.unlp.edu.ar) held in the city of La Plata in December 2007 and in the 12th University Library Meeting ${ }^{15}$ that took place in Buenos Aires in April 2008, with the idea of extending its application to the entire university libraries in Argentina.

\section{CONCLUSIONS AND FUTURE LINES OF WORK}

The results obtained so far have enabled us to observe and monitor the status of UNLP libraries from an analysis of their indicators. These results were obtained from the collection in standardized form of large amounts of statistical data, combined with one another, to show a picture of every studied aspect: infrastructure and equipment, collections, budget, personnel, services and users.

In turn, the obtained indicators have enabled us to compare ourselves with other libraries in other countries. Even if they face another context and historical time, this analysis provides us with a measure of our own development, and highlights the differences and gaps, for example, in connection with resources, when we compare ourselves with developed countries or with international standards.

In 2008 we have focused on improving the statistical form by incorporating some changes and clarifications based on the definitions of terms of ISO 2789, and the production of reports and summaries of data parametrization according to user requirements.

15 Organised in the context of ABGRA Annual Meeting, the Librarians Association of the Argentine Republic, more information is available at www.abgra.org.ar 
Despite the widespread use of this methodology in other countries, Argentina has a substantial backlog in the area, since it is relatively new the working with statistics and indicators generation. In this sense, our work has been exhibited in numerous meetings and events in the field, and we have become referents in this subject.

In our country, every single attempt and step towards the development of this area has been the result of self-motivated Library Directors. Unfortunately, there is neither an assembly of university libraries, nor a body that formally addresses the issue $^{16}$. For this reason, and by virtue on the progress achieved at UNLP, we thought of expanding and adapting our development and working methodology so that it can be used by the rest of Argentinian University Libraries that might wish to join this initiative and participate in a piloting experience.

However, for the project to have a national scope it requires an institutional commitment and steady funding to be sustained over the time. The UNLP through ROBLE is interested in maintaining the leadership in this issue, since we have been working in the necessary steps for its institutionalization and securing steady funding.

Based on the shared progress and accumulated experience at the UNLP, we are heading for the establishment of a community development project that involves different levels. We believe in contributing to shaping statistic database and collaborating on the design improvement, documentation, manuals, etc, as it occurs in open source projects.

The underlying philosophy is that of cooperative and distribute work, since each library provides and maintains its own data, and in return it can have access to the data from other libraries, to be used in its own analysis and benchmarking.

The IT development that resulted in the statistical database is free of charge and open to the public. Our project proposes a cooperative and distributed framework, with the idea of making and maintaining a Statistical Database of Argentinian University Libraries, which can be administered on a rotating basis from one of these cooperating universities.

Finally, it must be reiterated that the process of mapping and data loading carried out each year has shown significant weaknesses with training librarians to complete such tasks. There have been a number of constraints met and the solution seems to lie in implementing guidelines and standardized procedures for recording

16 DIBUN, the list of directors of national universities libraries that emerged in 2003 as a mailing list for discussion and treatment of common issues, is an initiative that is still forceful at some point, and was raised its constitution as an agency meeting. The CBA-Consortium of Argentinian Libraries-emerged at the behest of educ.ar was also raised as an instance of that meeting, that eventually failed. The SIULibraries module across the preparation of national union catalogs, and the advisory committee of the BECYT-Electronic Library of Science and Technology, are other spaces for directors' meeting for discussing various common goals. Finally the annual meetings of professionals working in university libraries -the ENBU, National University Library Meeting and JBDU, Conference of Digital University Library, both held in April and in October-are also areas where recursively meeting discussed these issues. 
statistics. The most critical problems are: lack of thoroughness in the processing of data, lack of uniformity in the form of recording, unreliable data, or complete absence of registration of such data.

\section{REFERENCES}

ANSI/NISO Z39.7-1995 Library Statistics - 39 p. - ISBN: 1-880124-27-0. - Disponible en PDF en: www.niso.org/standards [consulted 23/06/2003, currently not available]

ARL Statistics \& Measurement. Association of Research Libraries. - [on line] http://www.arl.org/stats/annualsurveys/arlstats/ [consulted 14/07/2008]

CARL Statistics. Canadian Associaton of Reseach Libraries [on line] http:// www.carl-abrc.ca/projects/statistics/statistics-e.html [consulted 06/07/ 2008]

CAUL Statistics. Council of Australian University Librarians [on line] http:// www.caul.edu.au/stats/ [consulted 06/07/2008]

CRUCH Consejo de Rectores de las Universidades Chilenas. CABID Comisión Asesora de Bibliotecas y Documentación (2003). Estándares para las bibliotecas universitarias chilenas [on line] $-2^{\mathrm{a}}$ ed. - Valparaiso : Universidad Católica de Valparaiso, 2003. - 48 p. - http://cabid.ucv.cl/files/estandares/standares.PDF [consulted 14/07/2008]

Fushimi, Marcela (2003). Autoevaluación de bibliotecas universitarias: Modelo de medición y diagnóstico a partir de datos estadísticos. - Trabajo final de grado (Licenciada en Bibliotecología y Documentación) Director: César Archuby Universidad Nacional de La Plata, Facultad de Humanidades y Ciencias de la Educación, Departamento de Bibliotecología, 2003: http://www. fuentesmemoria.fahce.unlp.edu.ar/tesis/te.294/te.294.pdf [consulted 15/06/ 2007]

ISO 2789-2003 Information and documentation : International Library Statistics. 3rd edition. - Geneva : ISO. $-52 \mathrm{p}$.

Parada, Alejandro E. (2003). Semblanza de Roberto Couture de Troistmonts, 1918-2001 : Una contribución a su biobibliografía. EN: Infodiversidad, 5 : 117134.

REBIUN (1999). Normas y directrices para bibliotecas universitarias y científicas. - [on line] - 2a ed. aumentada. - Madrid : Ministerio de Educación y Cultura. Dirección General del Libro. Archivos y bibliotecas, 1999. - http:// www.rebiun.org/doc/Bibliotecas\%20Universitarias\%20y\%20Científicas.pdf [consulted 14/07/2008]

SCONUL Statistics. Society of College, National \& University Libraries [on line] http://www.sconul.ac.uk/statistics/ [consulted 06/07/2008]

UNLP. Universidad Nacional de La Plata. [on line]. [consulted 06/07/2008]. $<$ http://www.unlp.edu.ar> 
UNLP. Anuario estadístico 2007: Informe anual comparado de indicadores de la UNLP. [on line]. - 1a ed. - La Plata : UNLP, 2008. [consulted 06/07/2008]. $<$ http://www.unlp.edu.ar/uploads/docs/anuario2007completo.pdf $>$

UNLP-ROBLE. Universidad Nacional de La Plata. ROBLE Red de Bibliotecas. [on line]. [consulted 06/07/2008]. <http://www.roble.unlp.edu.ar>

UNLP-ROBLE-ETI Evaluación de unidades de información. Formulario estadístico 2001 e Instructivo. [on line] - La Plata, 2002. [consulted 06/07/2008]. $<$ http://www.roble.unlp.edu.ar> Opción Estadísticas, Formularios

UNLP-ROBLE-ETI Evaluación de unidades de información. Anuario estadístico 2001 de las Bibliotecas de la UNLP. [on line] - La Plata, 2003. [consulted 06/07/2008]. - <http://www.roble.unlp.edu.ar> Opción Estadísticas, Anuarios

UNLP-ROBLE-ETI Evaluación de unidades de información. Formulario estadístico 2004 e Instructivo. [on line] - La Plata, 2005. [consulted 06/07/2008]. - <http://www.roble.unlp.edu.ar> Opción Estadísticas, Formularios

UNLP-ROBLE-ETI Evaluación de unidades de información. Anuario estadístico 2004 de las Bibliotecas de la UNLP. [on line] - La Plata, 2006. [consulted 06/07/2008]. - <http://www.roble.unlp.edu.ar> Opción Estadísticas, Anuarios

UNLP-ROBLE-ETI Evaluación de unidades de información. Formularios estadísticos de ROBLE. [on line] - La Plata, 2007. [consulted 06/07/2008]. $<$ http://www.roble.unlp.edu.ar> Opción Estadísticas, Formularios, Acceda a la aplicación Formularios estadísticos de ROBLE 